\title{
Cure in metastatic breast cancer
}

\author{
Theresa Westphal · Simon Peter Gampenrieder · Gabriel Rinnerthaler · Richard Greil
}

Received: 19 June 2018 / Accepted: 1 August 2018 / Published online: 17 August 2018

(C) The Author(s) 2018

Summary Oligometastatic disease characterizes a distinct subgroup of metastatic breast cancer patients that might benefit from different treatment strategies to achieve long-lasting remission and potentially cure. Those long-lasting remissions are reported after locoregional treatment of the primary tumor and all metastatic sites in several case series; however, unlike other tumor entities, prospective data are lacking. Furthermore, tumor eradication by excellent systemic anticancer therapy with novel chemotherapies and targeted agents can lead to long-term survival. In addition, reactivation of the host immune defense by immuno-oncologic drugs can achieve long-lasting tumor control. So far, unfortunately, checkpoint inhibitors as monotherapy have led to responses only in a small percentage of patients with metastatic breast cancer. This short review summarizes available data on long-lasting remissions and potential cure in metastatic breast cancers. It describes and discusses data on locoregional treatment, chemo-, antibody-

T. Westphal · S. P. Gampenrieder · G. Rinnerthaler · Prof. R. Greil $(\bowtie)$

IIIrd Medical Department with Hematology and Medical Oncology, Oncologic Center, Paracelsus Medical University Salzburg, Müllner Hauptstraße 48, 5020 Salzburg, Austria r.greil@salk.at

T. Westphal · S. P. Gampenrieder · G. Rinnerthaler • Prof. R. Greil

Salzburg Cancer Research Institute with Laboratory of Immunological and Molecular Cancer Research and Center for Clinical Cancer and Immunology Trials, Salzburg, Austria

Prof. R. Greil

Cancer Cluster Salzburg, Salzburg, Austria

T. Westphal · S. P. Gampenrieder · G. Rinnerthaler • Prof. R. Greil

Arbeitsgemeinschaft Medikamentöse Tumortherapie (AGMT), Vienna, Austria and immunotherapy and tries to select individual patients for whom a multidisciplinary treatment approach with curative intention might be an option to achieve long-term survival.

Keywords Oligometastatic · Surgery · Chemotherapy · Targeted therapy $\cdot$ Immunotherapy

\section{Introduction}

Metastatic breast cancer (MBC) has been synonymous with a lethal outcome and is generally considered incurable. Although there has been an improvement in overall survival (OS) during the last decades, survival rates are still low with 5-year and 10-year survival rates of $27 \%$ and $13 \%$, respectively [1].

It is of great interest to define subgroups of patients suffering from this heterogeneous disease that might benefit from different treatment strategies. One special subgroup comprises patients with limited tumor spread lying between localized early breast cancer and disseminated metastatic cancer, termed oligometastatic disease. In particular, oligometastatic tumors are characterized by solitary or few metastatic lesions that are usually limited to a single organ [2]. The 3rd ESO-ESMO (European School of Oncology-European Society for Medical Oncology) International Consensus Guidelines for Advanced Breast Cancer 3 (ABC 3) extended their definition of oligometastatic disease from a solitary organ to low volume metastatic disease with limited number and size of metastatic lesions (up to five and not necessarily in the same organ), potentially amenable for local treatment, aimed at achieving long-term remission [3].

In other tumor entities the goal of cancer treatment has already moved from palliation to cure in distinct oligometastatic patient subgroups. For ex- 
ample in colorectal cancer, long-term remission of oligometastatic lung or liver disease is achievable in a subgroup of patients and this strategy is part of established guidelines [4].

\section{Definition of cure in the metastatic disease}

There is no clear definition of cure in metastatic disease. The most realistic description for cure in cancer may be the following: those patients who die from other causes without any clinical evidence of cancer. As such, cure can only be defined retrospectively in an individual patient. Cure could also be understood as a state, where life expectancy of patients is comparable to a sex- and age-matched population. Additionally, a plateau in progression-free survival (PFS) and overall survival (OS) Kaplan-Meier curves may reflect the curative potential of a cancer treatment and serve as a surrogate for a subpopulation of patients with characteristic features.

In the commentary "International guidelines of metastatic breast cancer: can metastatic breast cancer be cured?" Pagani et al. discussed appropriate definitions and endpoints [2]. The authors state that complete remission and long-term PFS are usually surrogates for cure in metastatic cancer, but longterm survival might simply reflect an indolent nature of the disease rather than a long-term effect from therapy. Even more so, the lack of a common definition of curative treatment in the metastatic setting challenges the interpretation of the available heterogeneous data.

In order to cure metastatic disease, several approaches are imaginable: (1) locoregional treatment of the primary tumor and all metastatic sites, (2) tumor eradication by excellent systemic anticancer therapy, (3) long-term immunologic tumor control induced by immunotherapy or (4) the combination of these approaches.

\section{Long-term survival after surgery of distant metas- tases}

Despite good evidence for the resection of liver metastases in other entities like colorectal cancer, data in metastatic breast cancer (MBC) are limited [5]. Several heterogeneous case series [6-20] report a wide range of survival rates between 22 and 61 months in patients with MBC undergoing liver metastases resection (Table 1). In an update of a single-center experience $(n=51)$, Ercolani et al. reported a 10 -year OS rate of $16 \%$ [10]. More than half of these patients (8.9\%) were alive without evidence of recurrence since surgery. However, such patient cohorts are highly selected and it is likely that not only the resection itself is responsible for the good outcome but also the indolent course of disease or the specific genetic profile of the tumor and the ability of subclones to metastasize to a certain organ. In the article "Hepatic resection for metastatic breast cancer: an exercise in selection bias" D'Ángelica concluded that retrospective case series need reasonable comparative controls in order to reduce selection bias. Prospective randomized trials would be desirable, but such data are difficult to obtain [21]. In a small prospective data collection of 41 patients undergoing resection of liver metastases, positive resection margins and a short disease-free interval (DFI) until the detection of liver metastases were identified as potential factors associated with poor long-term survival [22].

Similar data are available for metastasectomy of pulmonary lesions [23-34]. In a systemic review including a meta-analysis, short DFI, incomplete resection of metastases, high number of metastases and negative hormone receptor status were identified as poor prognostic factors [35].

In Austria, a registry of the "Arbeitsgemeinschaft für medikamentöse Tumortherapie" (AGMT) specifically included MBC patients with surgical resection of solitary metastases and will further characterize patients with oligometastatic disease and collect survival data.

In summary, surgery of metastases is still experimental in MBC because valuable data from randomized trials and large cohorts are still missing. Even in the absence of radiologically detectable disseminated disease, $\mathrm{MBC}$ is in most of the cases a systemic disease and local treatment alone is not sufficient. However, the given data may help to characterize subgroups of patients with favorable outcome, where surgery could be an option in order to obtain long-term survival.

\section{Long-term survival induced by chemotherapy and targeted therapy}

Of all patients receiving chemotherapy for $\mathrm{MBC}$, only a few patients achieve a radiologic complete response (rCR) and an exceptional long remission [36, 37]. Additionally, those long-term survivors are not depicted in most MBC trials because follow-up is limited. A retrospective analysis including 75 patients aimed to characterize patients with long OS after a rCR [36]. After a median follow-up of 6 years, $28 \%$ of patients with rCR were still alive and $86 \%$ of those patients had no evidence of disease. In the multivariate analysis, anthracycline treatment and a good WHO performance status were independent predictors for longterm survival. Notably, in a historical cohort from the MD Anderson Cancer Center the percentage of longterm survivors was much lower (1-3\%; [37]).

A long-term follow-up analysis reports on 285 patients with single site recurrence $(76.5 \%$ locoregional, $23.5 \%$ distant) who had local treatment followed by chemotherapy. The median follow-up was 121 months and 20-year disease-free survival (DFS) and OS rates of patients with distant metastases were $18 \%$ and $21 \%$, respectively [38]. Similar results were published by Kobayashi et al. [39]. In their retrospective analysis of multidisciplinary treatments in 
Table 1 Case series of resection of liver metastases in MBC published within the last 20 years

\begin{tabular}{|c|c|c|c|}
\hline Author and reference & $n$ & Survival (\%) & Prognostic factors \\
\hline Raab et al. 1998 [6] & 34 & 5-year survival: 22 & Negative margins (R0), no prior local recurrence \\
\hline Pocard et al. 2000 [7] & 52 & 3-year survival: 49 & Long DFI \\
\hline Yoshimoto et al. 2000 [8] & 25 & 5-year survival: 27 & Not reported \\
\hline Pocard et al. 2001 [9] & 65 & 4-year survival: 46 & Long DFI \\
\hline Elias et al. 2003 [11] & 54 & 5-year survival: 34 & Positive hormone receptor status \\
\hline Vlastos et al. 2004 [14] & 31 & 5-year survival: 61 & Not reported \\
\hline Sakamoto Y et al. 2005 [15] & 35 & 5-year survival: 31 & No extrahepatic disease \\
\hline Adam et al. 2006 [16] & 85 & 5-year survival: 37 & $\begin{array}{l}\text { Response to preoperative chemotherapy, no R2 resection, possibility of } \\
\text { rehepatectomy in the further course of disease }\end{array}$ \\
\hline Zegarac M et al. 2013 [20] & 32 & Median OS 37 months & $\begin{array}{l}\text { Positive hormone receptor status, negative lymph nodes, long DFI, single } \\
\text { metastases }\end{array}$ \\
\hline Weinreich 2014 [12] & 21 & 5-year survival: 33 & $\begin{array}{l}\text { Negative margin (R0), low primary tumor size, negative lymph nodes, low- } \\
\text { grade histopathology, low number of liver metastases, long DFI }\end{array}$ \\
\hline Ye et al. 2015 [18] & 28 & $\begin{array}{l}5 \text {-year survival: } 53 \\
\text { 10-year survival: } 33\end{array}$ & $\begin{array}{l}\text { DFI > } 36 \text { months, negative margins, no tumor recurrence before metastec- } \\
\text { tomy }\end{array}$ \\
\hline Margonis et al. 2016 [17] & 131 & 3-year survival: 75.2 & Negative margin (R0), small diameter of the liver metastasis \\
\hline Kobryn et al. 2016 [19] & 30 & 3-year survival: 36.4 & Not reported \\
\hline Ercolani et al. 2005 [13] and 2018 [10] & 51 & $\begin{array}{l}\text { 5-year survival: } 36 \\
\text { 10-year survival: } 16\end{array}$ & $\begin{array}{l}\text { Small tumor diameter, positive progesterone receptor status, and triple } \\
\text { negative status }\end{array}$ \\
\hline
\end{tabular}

75 patients with one or two organs involved (excluding the primary lesion resectable by surgery), an exceptional median OS of 185 months and a relapsefree interval of 48 months was reported. No disease progression was observed after 101 months of relapsefree survival.

Several phase III clinical trials investigating specific drugs, reported extraordinarily long median OS times. The CLEOPATRA trial, for example, reported a median OS of 56.5 months (95\%CI 49.3 months to not reached) with the combination of docetaxel, trastuzumab and pertuzumab as first-line treatment in patients with human epidermal growth factor receptor 2 (HER2+) MBC [40]. In estrogen receptor (ER)+/HER2- MBC, the introduction of cyclin-dependent kinase 4/6 (CDK4/6) inhibitors led to comparable excitement. The addition to standard endocrine therapy almost doubled median PFS times in all phase III trials published today [41-46]. Currently, OS data are available from the pilot phase II PALOMA 1 trial only, where patients with ER+/HER2- MBC were treated first-line with palbociclib plus letrozole. The median OS was 37.5 months; however, some patients in this trial are still on this drug combination for now more than 6 years [47].

These trial results suggest that a few patients with MBC can achieve long-term survival (with or without complete remission of the disease), when treated with effective anticancer agents. In general, continuation of therapy is however needed to maintain this success. Therefore, effective systemic maintenance treatments with a favorable toxicity profile are needed to reach cure in the narrower sense of the word. Further longterm studies or high-level registries will help to iden- tify and characterize those patients with exceptional outcomes induced by systemic treatment.

\section{Long-term survival induced by immunotherapy}

The introduction of checkpoint inhibitors like anticytotoxic T-lymphocyte-associated protein 4 (antiCTLA4)-, anti-programmed cell death protein 1(antiPD1)- and anti-programmed cell death protein ligand 1 (anti-PD-L1) antibodies led to a paradigm shift in oncology. In metastatic melanoma, where overall survival was invariably short and mortality was $100 \%$, long-term survival was reached in trials with checkpoint inhibitors. A pooled analysis of 12 trials investigating the CTLA4 antibody ipilimumab including 1861 patients with metastatic melanoma showed a 3-year survival rate of $22 \%$ (95\%CI 20-24\%; [48]). In trials testing anti-PD1- or anti-PD-L1 antibodies or the combination of ipilimumab and anti-PD1 antibodies, the percentage of patients with long-term survival seems to be even higher [49-51], raising the discussion about the curability of this disease. Encouraging results were also reported in non-small cell lung cancer [52-54], renal cell cancer [55] and bladder cancer [56, 57].

In MBC, only a few phase I and phase II trials investigating checkpoint inhibitors are available today ([58-62]; Table 2). Overall response rates (ORR) were moderate, but like in other diseases, durable responses in those patients responding to therapy were reported [58, 59, 63]. The longest follow-up is reported in the phase I trial Keynote-012, investigating the anti-PD1 antibody pembrolizumab as monotherapy in triple-negative MBC [58, 63]. Most of the patients were heavily pretreated with $47 \%$ of the patients 
Table 2 Overall response rates (ORR) and ongoing responses in phase I-II trials with checkpoint inhibitors in metastatic breast cancer

\begin{tabular}{|c|c|c|c|c|c|c|}
\hline & \multicolumn{3}{|c|}{ ER+/HER2- } & \multicolumn{3}{|c|}{ TNBC } \\
\hline & $n$ & ORR & Ongoing responses & $n$ & ORR & Ongoing responses \\
\hline \multicolumn{7}{|l|}{ Pembrolizumab (anti-PD-1) } \\
\hline Keynote-012 (phase lb; [58]) & - & - & - & $32^{\mathrm{a}}$ & $18 \%$ & $11 \%(>1$ year) \\
\hline Keynote-086 (phase II) cohort A [60] & - & - & - & 170 & $5 \%$ & $0 \%$ \\
\hline Keynote-086 (phase II) cohort B [59] & - & - & - & $52^{\mathrm{a}}$ & $23 \%$ & $29 \%$ ( $>1$ year) \\
\hline Keynote-028 (phase lb; [61]) & $25^{\mathrm{a}}$ & $12 \%$ & $0 \%$ & - & - & - \\
\hline \multicolumn{7}{|l|}{ Atezolizumab (anti-PD-L1) } \\
\hline Schmid P. (phase la; [62]) & - & - & - & 112 & $17 \%$ & n.g. \\
\hline \multicolumn{7}{|l|}{ Avelumab (anti-PD-L1) } \\
\hline JAVELIN (phase lb; [65]) & 72 & $3 \%$ & $4 \%$ (overall) & 58 & $5 \%$ & $4 \%$ (overall) \\
\hline
\end{tabular}

having more than two prior lines of chemotherapy at study entry. The ORR was $18.5 \%$, and the median OS was 10 months (95\%CI 5.3-17.5). However, three of the five $(60 \%)$ responding patients had long-lasting responses. After a median follow-up of 10.7 months, median duration of response was not reached and ranged from 15 to $\geq 47$ weeks. One patient discontinued pembrolizumab 11 months after achieving complete remission and was still in complete remission 18 months later, without further anticancer therapy. Since the estimated response to chemotherapy in this population ranges from 4 to 12 weeks, these results are promising [64].

Checkpoint inhibitors were also tested in patients with HR-positive MBC. The phase Ib trial Keynote-028 investigating pembrolizumab monotherapy included a cohort of 25 patients with HR-positive MBC. Only 3 patients experienced partial response (ORR 12\%); however, the median duration of response was 12.0 months (range, 7.4-15.9 months; [61]). In the phase Ib trial JAVELIN, 58 patients with triple-negative and 72 patients with HR-positive MBC were treated with the anti-PD-L1 antibody avelumab [65]. In the HRpositive subgroup the confirmed ORR was only $3 \%$. Of the 47 patients with a best response of complete response, partial response or stable disease, 14 (30\%) remained progression free for $\geq 24$ weeks.

Based on results from the Keynote-012 and Keynote-086 trials, pembrolizumab will probably soon be the first checkpoint inhibitor licensed by the US Food and Drug Administration and the European Medicines Agency for the treatment of MBC. Nevertheless, because of the low percentage of patients benefiting from single-agent checkpoint inhibitor therapy, combination strategies will be required in order to increase the success rate of immunotherapy in MBC.

\section{Early detection of metastatic disease in an oligometastatic state}

Locoregional treatment strategies are generally limited to patients with oligometastatic disease. Therefore, patients might benefit from early detection of metastatic disease after early breast cancer treatment. Using sensitive diagnostic tools like positron emission tomography/computed tomography (PET-CT; [66]) or liquid biopsies might help to detect metastasis much earlier. Liquid biopsies nowadays allow detection of circulating tumor deoxyribonucleic acid (ctDNA); [67, 68]), circulating tumor cells [69], circulating exosomes [70], circulating micro ribonucleic acids (microRNAs) [71] or tumor-educated blood platelets (TEP; [72]). However, by earlier detection, survival time of patients might falsely increase due to lead time bias [2]. Biological characteristics including molecular breast cancer subtypes, specific mutations or microRNA profiles [73] might additionally help selecting patients for certain specific therapeutic strategies leading to longterm tumor control.

\section{Conclusion}

With improved treatment options and individualized treatment strategies cure might be an achievable goal for highly selected patients with MBC. Specifically, in oligometastatic disease, where a combination of local and systemic treatment is feasible, such long-term effects can be achieved. According to the current literature, long-term disease-free survival can be observed after surgery of distant metastases; however, the biology of the disease has to be considered when patients are selected for such an approach. Unfortunately, valuable comparative data are still missing, for which reason surgery of breast cancer metastases still remains experimental and an individual decision. Chemotherapy, as well as targeted therapies, can lead to long-lasting disease control. Since it is unknown if systemic therapy can be stopped in case of long- 
lasting complete remission, therapy is generally continued. Therefore, a favorable toxicity profile is one of the requirements for a systemic therapy with curative potential. Reactivation of the host immune defense by immuno-oncologic drugs can achieve long-lasting tumor controls. Unfortunately, checkpoint-inhibitors as monotherapy lead to responses only in a small percentage of patients with MBC. Therefore, combination strategies are needed in order to increase the probability for tumor shrinkage, long-term responses and finally cure.

Since for all of these strategies low volume disease increases the success rate, early detection of metastatic disease might be one step forward. New technologies in imaging and liquid biopsies could help in this regard. Finally, only selection of patients for individualized treatment options in an interdisciplinary environment will help to establish a cure for MBC in the future.

Funding Open access funding provided by Paracelsus Medical University.

Conflict of interest T. Westphal, S.P. Gampenrieder, G. Rinnerthaler and R. Greil declare that they have no competing interests.

Open Access This article is distributed under the terms of the Creative Commons Attribution 4.0 International License (http://creativecommons.org/licenses/by/4.0/), which permits unrestricted use, distribution, and reproduction in any medium, provided you give appropriate credit to the original author(s) and the source, provide a link to the Creative Commons license, and indicate if changes were made.

\section{References}

1. Eng LG, Dawood S, Sopik V, Haaland B, Tan PS, Bhoo-Pathy N, Warner E, Iqbal J, Narod SA, Dent R. Ten-year survival in women with primary stage IV breast cancer. Breast Cancer Res Treat. 2016;160(1):145-52. https://doi.org/10.1007/ s10549-016-3974-X.

2. Pagani O, SenkusE, WoodW, Colleoni M, Cufer T, Kyriakides S, Costa A, Winer EP, Cardoso F, Force E-MT. International guidelines for management of metastatic breast cancer: can metastatic breast cancer be cured? J Natl Cancer Inst. 2010;102 (7):456-63. https://doi.org/10.1093/jnci/djq029.

3. Cardoso F, Costa A, Senkus E, Aapro M, Andre F, Barrios CH, Bergh J, Bhattacharyya G, Biganzoli L, Cardoso MJ, Carey L, Corneliussen-James D, Curigliano G, Dieras V, El Saghir N, Eniu A, Fallowfield L, Fenech D, Francis P, Gelmon K, Gennari A, Harbeck N, Hudis C, Kaufman B, Krop I, Mayer M, Meijer H, Mertz S, Ohno S, Pagani O, Papadopoulos E, Peccatori F, Penault-Llorca F, Piccart MJ, Pierga JY, Rugo H, Shockney L, Sledge G, Swain S, Thomssen C, TuttA, Vorobiof D, Xu B, Norton L, Winer E. 3rd ESO-ESMO international consensus guidelines for Advanced Breast Cancer (ABC 3). Ann Oncol. 2017;28(1):16-33. https://doi.org/10.1093/ annonc/mdw544.

4. Van Cutsem E, Cervantes A, Nordlinger B, Arnold D, Group EGW. Metastatic colorectal cancer: ESMO clinical practice guidelines for diagnosis, treatment and follow-up. Ann Oncol. 2014;25(Suppl3):iiil-iii9. https://doi.org/10.1093/ annonc/mdu260.
5. Huang F, Wu G, Yang K. Oligometastasis and oligo-recurrence: more than a mirage. Radiat Oncol. 2014;9:230. https://doi.org/10.1186/s13014-014-0230-6.

6. Raab R, Nussbaum KT, Behrend M, Weimann A. Liver metastases of breast cancer: results of liver resection. Anticancer Res. 1998;18(3C):2231-3.

7. Pocard M, Pouillart P, Asselain B, Salmon R. Hepatic resection in metastatic breast cancer: results and prognostic factors. Eur J Surg Oncol. 2000;26(2):155-9. https://doi. org/10.1053/ejso.1999.0761.

8. Yoshimoto M, Tada T, Saito M, Takahashi K, Makita M, Uchida Y, Kasumi F. Surgical treatment of hepatic metastases from breast cancer. Breast Cancer Res Treat. 2000;59(2):177-84. https://doi.org/10.1023/a: 1006398401352.

9. Pocard M, Pouillart P, Asselain B, Falcou MC, Salmon RJ. Hepatic resection for breast cancer metastases: results and prognosis (65 cases). Ann Chir. 2001;126(5):413-20.

10. Ercolani G, Zanello M, Serenari M, Cescon M, Cucchetti A, Ravaioli M, Del Gaudio M, D’Errico A, Brandi G, Pinna AD. Ten-year survival after liver resection for breast metastases: a single-center experience. Dig Surg. 2018; https://doi.org/ $10.1159 / 000486523$.

11. Elias D, MaisonnetteF, Druet-Cabanac M, OuelletJF, Guinebretiere JM, Spielmann M, Delaloge S. An attempt to clarify indications for hepatectomy for liver metastases from breast cancer. Am J Surg. 2003;185(2):158-64.

12. Weinrich M, Weiss C, Schuld J, Rau BM. Liver resections of isolated liver metastasis in breast cancer: results and possible prognostic factors. HPB Surg. 2014;2014:893829. https://doi.org/10.1155/2014/893829.

13. Ercolani G, Grazi GL, Ravaioli M, Ramacciato G, Cescon M, Varotti G, Del Gaudio M, Vetrone G, Pinna AD. The role of liver resections for noncolorectal, nonneuroendocrine metastases: experience with 142 observed cases. Ann Surg Oncol. 2005;12(6):459-66. https://doi.org/10.1245/ASO. 2005.06.034.

14. Vlastos G, Smith DL, Singletary SE, Mirza NQ, Tuttle TM, Popat RJ, Curley SA, Ellis LM, Roh MS, Vauthey JN. Longterm survival after an aggressive surgical approach in patients with breast cancer hepatic metastases. Ann Surg Oncol. 2004;11(9):869-74. https://doi.org/10.1245/ASO. 2004.01.007.

15. Sakamoto Y, Yamamoto J, Yoshimoto M, Kasumi F, Kosuge T, Kokudo N, Makuuchi M. Hepatic resection for metastatic breast cancer: prognostic analysis of 34 patients. World J Surg. 2005;29(4):524-7. https://doi.org/10.1007/s00268004-7688-6.

16. Adam R, Aloia T, Krissat J, Bralet MP, Paule B, Giacchetti S, Delvart V, Azoulay D, Bismuth H, Castaing D. Is liver resectionjustified for patients with hepatic metastases from breast cancer? Ann Surg. 2006;244(6):897-907. https:// doi.org/10.1097/01.sla.0000246847.02058.1b. discussion 907-898.

17. Margonis GA, Buettner S, Sasaki K, Kim Y, Ratti F, Russolillo N, Ferrero A, Berger N, Gamblin TC, Poultsides G, Tran T, Postlewait LM, Maithel S, Michaels AD, Bauer TW, Marques H, Barroso E, Aldrighetti L, Pawlik TM. The role of liverdirected surgery in patients with hepatic metastasis from primary breast cancer: a multi-institutional analysis. HPB (Oxford). 2016;18(8):700-5. https://doi.org/10.1016/j.hpb. 2016.05.014.

18. Ye T, Yang B, Tong H, Zhang Y, Xia J. Long-term outcomes of surgical resection for liver metastasis from breast cancer. Hepatogastroenterology. 2015;62(139):688-92.

19. Kobryn E, Kobryn K, Wroblewski T, Kobryn K, Pietrzak R, Rykowski P, Ziarkiewicz-Wroblewska B, Lamparski K, 
Zieniewicz K, Patkowski W, Krawczyk M, Paluszkiewicz $R$. Is there a rationale for aggressive breast cancer liver metastases resections in Polish female patients? Analysis of overall survival following hepatic resection at a single centre in Poland. Ann Agric Environ Med. 2016;23(4):683-7. https:// doi.org/10.5604/12321966.1226866.

20. Zegarac M, Nikolic S, Gavrilovic D, Jevric M, Kolarevic D, Nikolic-Tomasevic Z, Kocic M, Djurisic I, Inic Z, Ilic V, Santrac N. Prognostic factors for longer disease free survival and overall survival after surgical resection of isolated liver metastasis from breast cancer. JBuon. 2013;18(4):859-65.

21. D'Angelica M. Hepatic resection for metastatic breast cancer: an exercise in selection bias. HPB (Oxford). 2016;18(8):631-2. https://doi.org/10.1016/j.hpb.2016.07. 003.

22. Hoffmann K, Franz C, Hinz U, Schirmacher P, Herfarth C, Eichbaum M, Buchler MW, Schemmer P. Liver resection for multimodal treatment of breast cancer metastases: identification of prognostic factors. Ann Surg Oncol. 2010;17(6):1546-54. https://doi.org/10.1245/s10434-0100931-5.

23. Friedel G, Pastorino U, Ginsberg RJ, Goldstraw P, Johnston M, Pass H, Putnam JB, Toomes H, International Registry of Lung Metastases L. Results of lung metastasectomy from breast cancer: prognostic criteria on the basis of 467 cases of the International Registry of Lung Metastases. Eur J Cardiothorac Surg. 2002;22(3):335-44.

24. Livartowski A, Chapelier A, Beuzeboc P, Dierick A, Asselain B, Dartevelle P, Pouillart P. Surgical excision of pulmonary metastasis of cancer of the breast: apropos of 40 patients. Bull Cancer. 1998;85(9):799-802.

25. Murabito M, Salat A, Mueller MR. Complete resection of isolated lung metastasis from breast carcinoma results in a strong increase in survival. Minerva Chir. 2000;55(3):121-7.

26. Ludwig C, Stoelben E, Hasse J. Disease-free survival after resection of lung metastases in patients with breast cancer. EurJSurg Oncol. 2003;29(6):532-5.

27. Planchard D, Soria JC, Michiels S, Grunenwald D, Validire P, Caliandro R, Girard P, Le Chevalier T. Uncertain benefit from surgery in patients with lung metastases from breast carcinoma. Cancer. 2004;100(1):28-35. https://doi.org/10. $1002 /$ cncr.11881.

28. Tanaka F, Li M, Hanaoka N, Bando T, Fukuse T, Hasegawa $\mathrm{S}$, Wada $\mathrm{H}$. Surgery for pulmonary nodules in breast cancer patients. Ann Thorac Surg. 2005;79(5):1711-4. https://doi.org/10.1016/j.athoracsur.2004.10.033. discussion 1714-1715.

29. Rena O, Papalia E, Ruffini E, Filosso PL, Oliaro A, Maggi G, Casadio C. The role of surgeryin the management of solitary pulmonary nodule in breast cancer patients. Eur J Surg Oncol. 2007;33(5):546-50. https://doi.org/10.1016/j.ejso. 2006.12.015.

30. Welter S, Jacobs J, KrbekT, Totsch M, Stamatis G. Pulmonary metastases of breast cancer. When is resection indicated? Eur J Cardiothorac Surg. 2008;34(6):1228-34. https://doi. org/10.1016/j.ejcts.2008.07.063.

31. Chen F, Fujinaga T, Sato K, Sonobe M, Shoji T, Sakai H, Miyahara R, Bando T, Okubo K, Hirata T, Toi M, DateH.Clinical features of surgical resection for pulmonary metastasis from breast cancer. Eur J Surg Oncol. 2009;35(4):393-7. https://doi.org/10.1016/j.ejso.2008.05.005.

32. Meimarakis G, Ruttinger D, Stemmler J, Crispin A, Weidenhagen R, Angele M, Fertmann J, Hatz RA, Winter H. Prolonged overall survival after pulmonary metastasectomy in patients with breast cancer. Ann Thorac Surg. 2013;95(4):1170-80. https://doi.org/10.1016/j.athoracsur. 2012.11.043.
33. Kycler W, Laski P. Surgical approach to pulmonary metastases from breast cancer. Breast J. 2012;18(1):52-7. https:// doi.org/10.1111/j.1524-4741.2011.01176.x.

34. Yoshimoto M, Tada K, Nishimura S, Makita M, Iwase T, Kasumi F, Okumura S, Sato Y, Nakagawa K. Favourable longterm results after surgical removal of lung metastases of breast cancer. Breast Cancer Res Treat. 2008;110(3):485-91. https://doi.org/10.1007/s10549-007-9747-9.

35. Fan J, Chen D, Du H, Shen C, Che G. Prognostic factors for resection of isolated pulmonary metastases in breast cancer patients: a systematic review and meta-analysis. JThorac Dis. 2015;7(8):1441-51. https://doi.org/10.3978/j. issn.2072-1439.2015.08.10.

36. Tomiak E, Piccart M, Mignolet F, Sahmoud T, Paridaens R, Nooy M, Beex L, Fentiman IS, Muller A, van der Schueren E, Rubens RD. Characterisation of complete responders to combination chemotherapy for advanced breast cancer: a retrospective EORTC Breast Group study. Eur J Cancer. 1996;32A(11):1876-87.

37. Greenberg PA, Hortobagyi GN, Smith TL, Ziegler LD, Frye DK, Buzdar AU. Long-term follow-up of patients with complete remission following combination chemotherapy for metastaticbreastcancer. JClinOncol. 1996;14(8):2197-205. https://doi.org/10.1200/JCO.1996.14.8.2197.

38. Hanrahan EO, Broglio KR, Buzdar AU, Theriault RL, Valero V, Cristofanilli M, Yin G, Kau SW, Hortobagyi GN, Rivera E. Combined-modality treatment for isolated recurrences of breast carcinoma: update on 30 years of experience at the University of Texas M.D. Anderson Cancer Center and assessment of prognostic factors. Cancer. 2005;104(6):1158-71. https://doi.org/10.1002/cncr.21305.

39. Kobayashi T, Ichiba T, Sakuyama T, Arakawa Y, Nagasaki E, Aiba K, Nogi H, Kawase K, Takeyama H, Toriumi Y, Uchida K, Kobayashi M, Kanehira C, Suzuki M, Ando N, Natori K, KuraishiY.Possible clinical cure of metastatic breast cancer: lessons from our 30-year experience with oligometastatic breast cancer patients and literature review. Breast Cancer. 2012;19(3):218-37. https://doi.org/10.1007/s12282-0120347-0.

40. Swain SM, Baselga J, Kim SB, Ro J, Semiglazov V, Campone M, Ciruelos E, Ferrero JM, Schneeweiss A, Heeson S, Clark E, Ross G, Benyunes MC, Cortes J, Group CS. Pertuzumab, trastuzumab, and docetaxel in HER2-positive metastatic breast cancer. N Engl J Med. 2015;372(8):724-34. https:// doi.org/10.1056/NEJMoa1413513.

41. Finn RS, Martin M, Rugo HS, Jones S, Im SA, Gelmon K, Harbeck N, Lipatov ON, Walshe JM, Moulder S, Gauthier E, Lu DR, Randolph S, Dieras V, Slamon DJ. Palbociclib and Letrozole in advanced breast cancer. N Engl J Med. 2016;375(20):1925-36. https://doi.org/10.1056/ NEJMoa1607303.

42. Cristofanilli M, Turner NC, Bondarenko I, Ro J, Im S-A, Masuda N, Colleoni M, DeMichele A, Loi S, Verma S, Iwata $\mathrm{H}$, Harbeck N, Zhang K, Theall KP, Jiang Y, Bartlett CH, Koehler M, Slamon D. Fulvestrant plus palbociclib versus fulvestrant plus placebo for treatment of hormone-receptor-positive, HER2-negative metastatic breast cancer that progressed on previous endocrine therapy (PALOMA-3). LancetOncol. 2016;17(4):425-39. https://doi.org/10.1016/ S1470-2045(15)00613-0. final analysis of the multicentre, double-blind, phase 3 randomised controlled trial.

43. Hortobagyi GN, Stemmer SM, Burris HA, Yap YS, Sonke GS, Paluch-ShimonS, CamponeM, BlackwellKL, AndreF, Winer EP, Janni W, Verma S, Conte P, Arteaga CL, Cameron DA, Petrakova K, Hart LL, Villanueva C, Chan A, Jakobsen E, Nusch A, Burdaeva O, Grischke EM, Alba E, Wist E, Marschner N, Favret AM, Yardley D, Bachelot T, Tseng LM, Blau S, Xuan 
F, Souami F, Miller M, Germa C, Hirawat S, O'Shaughnessy J. Ribociclib as first-line therapy for HR-positive, advanced breast cancer. NEngl J Med. 2016;375(18):1738-48. https:/ / doi.org/10.1056/NEJMoa1609709.

44. Fasching PA, Jerusalem GHM, Pivot X, Martin M, Laurentiis MD, Blackwell KL, Esteva FJ, Chia SKL, Germa C, Tang Z, Dhuria SV, Slamon DJ. Phase III study of ribociclib (LEE011) plus fulvestrant for the treatment of postmenopausal patients with hormone receptor-positive (HR+), human epidermal growth factor receptor 2-negative (HER2-) advanced breast cancer (aBC). J Clin Oncol. 2016;34(15 suppl):TPS624-TPS624. https://doi.org/ 10.1200/JCO.2016.34.15_suppl.TPS624. who have received no or only one line of prior endocrine treatment (ET): MONALEESA-3.

45. Sledge GW Jr., Toi M, Neven P, Sohn J, Inoue K, Pivot X, Burdaeva O, Okera M, Masuda N, Kaufman PA, Koh H, GrischkeEM, Frenzel M, Lin Y, Barriga S, Smith IC, Bourayou $\mathrm{N}$, Llombart-Cussac A. MONARCH 2: Abemaciclib in combination with Fulvestrant in women with HR+/HER2- advanced breast cancer who had progressed while receiving endocrine therapy. J Clin Oncol. 2017;35(25):2875-84. https://doi.org/10.1200/JCO.2017.73.7585.

46. Goetz MP, Toi M, Campone M, Sohn J, Paluch-Shimon S, Huober J, Park IH, Tredan O, Chen SC, Manso L, Freedman OC, Garnica Jaliffe G, Forrester T, Frenzel M, Barriga S, Smith IC, Bourayou N, Di Leo A. MONARCH 3: Abemaciclib as initial therapy for advanced breast cancer. J Clin Oncol. 2017;35(32):3638-46. https://doi.org/10.1200/JCO.2017. 75.6155.

47. Finn RS, Crow JP, Lang I, Boer K, Bondarenko I, Kulyk SO, Ettl J, Patel R, Pinter T, Schmidt M, Shparyk YV, Thummala A, Voytko NL, Fowst C, Huang X, Kim S, Slamon DJ. Overall survival results from the randomized phase II study of palbociclib (P) in combination with letrozole (L) vs letrozole alone for frontline treatment of ER+/HER2-advanced breast cancer (PALOMA-1; TRIO-18). J Clin Oncol. 2017; https://doi.org/10.1200/JCO.2017.35.15_suppl.1001.

48. Schadendorf D, Hodi FS, Robert C, Weber JS, Margolin K, Hamid O, Patt D, Chen TT, Berman DM, Wolchok JD. Pooled analysis of long-term survival data from phaseII and phase III trials of ipilimumab in unresectable or metastatic melanoma. JClin Oncol. 2015;33(17):1889-94. https:// doi. org/10.1200/JCO.2014.56.2736.

49. Larkin J, Chiarion-Sileni V, Gonzalez R, Rutkowski P, Grob J-J, Cowey CL, Lao CD, Schadendorf D, Ferrucci PF, Smylie M, Dummer R, Hill A, Haanen J, Maio M, McArthur G, Walker D, Rollin L, Horak C, Hodi FS, Wolchok JD. Abstract CT075: overall survival (OS) results from a phase III trial of nivolumab (NIVO) combined with ipilimumab (IPI) in treatment-naïve patients with advanced melanoma (CheckMate 067). Cancer Res. 2017;77(13 Suppl):CT75-CT75. https://doi.org/10.1158/1538-7445.am2017-ct075.

50. Robert C, Long GV, Schachter J, Arance A, Grob JJ, Mortier L, Daud A, Carlino MS, McNeil CM, Lotem M, Larkin JMG, Lorigan P, Neyns B, Blank CU, Petrella TM, Hamid $\mathrm{O}$, Zhou H, Moreno BH, Ibrahim N, Ribas A. Long-term outcomes in patients (pts) with ipilimumab (ipi)-naive advanced melanoma in the phase 3 KEYNOTE-006 study who completed pembrolizumab (pembro) treatment. JClin Oncol. 2017;35(15 suppl):9504-9504. https://doi.org/10. 1200/JCO.2017.35.15_suppl.9504.

51. Robert C, Schachter J, Long GV, Arance A, Grob JJ, Mortier L, Daud A, Carlino MS, McNeil C, Lotem M, Larkin J, Lorigan P, Neyns B, Blank CU, Hamid O, Mateus C, Shapira-Frommer R, Kosh M, Zhou H, Ibrahim N, Ebbinghaus S, Ribas A, investigators K-. Pembrolizumab versus Ipilimumab in advanced melanoma. N Engl J Med. 2015;372(26):2521-32. https://doi.org/10.1056/NEJMoa1503093.

52. Brahmer J, Reckamp KL, Baas P, Crino L, Eberhardt WE, Poddubskaya E, Antonia S, Pluzanski A, Vokes EE, Holgado E, Waterhouse D, Ready N, Gainor J, Frontera AO, Havel L, Steins M, Garassino MC, Aerts JG, Domine M, Paz-Ares L, Reck M, Baudelet C, Harbison CT, Lestini B, Spigel DR. Nivolumab versus Docetaxel in advanced squamous-cell non-small-cell lung cancer. N Engl J Med. 2015;373(2):123-35. https://doi.org/10.1056/ NEJMoa1504627.

53. Herbst RS, Baas P, Kim DW, Felip E, Perez-Gracia JL, Han JY, Molina J, Kim JH, Arvis CD, Ahn MJ, Majem M, Fidler MJ, de Castro G Jr., Garrido M, Lubiniecki GM, Shentu Y, Im E, Dolled-Filhart M, Garon EB. Pembrolizumab versus docetaxel for previously treated, PD-L1-positive, advanced non-small-cell lung cancer (KEYNOTE-010): a randomised controlled trial. Lancet. 2016;387(10027):1540-50. https:// doi.org/10.1016/S0140-6736(15)01281-7.

54. Rittmeyer A, Barlesi F, Waterkamp D, Park K, Ciardiello F, von Pawel J, Gadgeel SM, Hida T, Kowalski DM, Dols MC, Cortinovis DL, Leach J, Polikoff J, Barrios C, Kabbinavar F, Frontera OA, De Marinis F, Turna H, Lee JS, Ballinger M, Kowanetz M, He P, Chen DS, Sandler A, Gandara DR, Group OAKS. Atezolizumab versus docetaxel in patients with previously treated non-small-cell lung cancer (OAK): a phase 3, open-label, multicentre randomised controlled trial. Lancet. 2017;389(10066):255-65. https://doi.org/10. 1016/S0140-6736(16)32517-X.

55. Motzer RJ, Tannir NM, McDermott DF, Frontera AO, Melichar B, Choueiri TK, Plimack ER, Barthelemy P, Porta C, George S, Powles T, Donskov F, Neiman V, Kollmannsberger CK, Salman P, Gurney H, Hawkins R, Ravaud A, Grimm MO, Bracarda S, Barrios CH, Tomita Y, Castellano D, Rini BI, Chen AC, Mekan S, McHenry MB, Wind-Rotolo M, Doan J, Sharma P, Hammers HJ, Escudier B, CheckMate I. Nivolumab plus Ipilimumab versus Sunitinib in advanced renal-cell carcinoma. N Engl J Med. 2018;378(14):1277-90. https://doi.org/10.1056/NEJMoa1712126.

56. Rosenberg JE, Hoffman-Censits J, Powles T, van der Heijden MS, Balar AV, Necchi A, Dawson N, O’Donnell PH, Balmanoukian A, Loriot Y, Srinivas S, Retz MM, Grivas P, Joseph RW, Galsky MD, Fleming MT, Petrylak DP, Perez-Gracia JL, Burris HA, Castellano D, Canil C, Bellmunt J, Bajorin D, Nickles D, Bourgon R, Frampton GM, Cui N, Mariathasan S, Abidoye O, Fine GD, Dreicer R. Atezolizumab in patients with locally advanced and metastatic urothelial carcinoma who have progressed following treatment with platinumbased chemotherapy: a single-arm, multicentre, phase 2 trial. Lancet. 2016;387(10031):1909-20. https://doi.org/10. 1016/S0140-6736(16)00561-4.

57. Sharma P, Retz M, Siefker-Radtke A, Baron A, Necchi A, Bedke J, Plimack ER, Vaena D, Grimm M-O, Bracarda S, Arranz JÁ, Pal S, Ohyama C, Saci A, Qu X, Lambert A, Krishnan S, Azrilevich A, Galsky MD. Nivolumab in metastatic urothelial carcinoma after platinum therapy (CheckMate 275): a multicentre, single-arm, phase 2 trial. Lancet Oncol. 2017;18(3):312-22.https://doi.org/10.1016/ S1470-2045(17)30065-7.

58. Nanda R, Specht J, Dees EC, Berger R, Gupta S, Geva R, Pusztai L, Pathiraja K, Ray A, Karantza V, Buisseret L. Pembrolizumab for metastatic triple-negative breast cancer (mTNBC): long-lasting responses in the phase Ib KEYNOTE-012 study. Eur J Cancer. 2017;72:S38. https:// doi.org/10.1016/S0959-8049(17)30206-X.

59. Adams S, Loi S, Toppmeyer D, Cescon DW, Laurentiis MD, Nanda R, Winer EP, Mukai H, Tamura K, Armstrong A, Liu 
MC, Iwata H, Ryvo L, Wimberger P, Card D, Ding Y, Karantza $\mathrm{V}$, Schmid P. Phase 2 study of pembrolizumab as firstline therapy for PD-L1 - positive metastatic triple-negative breast cancer (mTNBC): preliminary data from KEYNOTE086 cohort B. J Clin Oncol. 2017;35(15 suppl):1088-1088. https://doi.org/10.1200/JCO.2017.35.15_suppl.1088.

60. Adams S, Schmid P, Rugo HS, Winer EP, Loirat D, Awada A, Cescon DW, Iwata H, Campone M, Nanda R, Hui R, Curigliano G, Toppmeyer D, O'ShaughnessyJ, LoiS, PaluchShimon S, Card D, Zhao J, Karantza V, Cortes J. Phase 2 study of pembrolizumab (pembro) monotherapy for previously treated metastatic triple-negative breast cancer (mTNBC): KEYNOTE-086 cohortA. JClin Oncol.2017;35(15 suppl):1008-1008. https://doi.org/10.1200/JCO.2017.35. 15_suppl.1008.

61. Rugo HS, Delord JP, Im SA, Ott PA, Piha-Paul SA, Bedard PL, Sachev J, Le Tourneau C, van Brummelen EMJ, Varga A, Salgado R, Loi S, Saraf S, Pietrangelo D, Karantza V, Tan AR. Safety and antitumor activity of Pembrolizumab in patients with estrogen receptorpositive/human epidermal growth factor receptor 2negative advanced breast cancer. Clin Cancer Res. 2018; https://doi.org/10.1158/1078-0432. CCR-17-3452.

62. Schmid P, Cruz C, Braiteh FS. Atezolizumab in metastatic triple-negative breast cancer: long-term clinical outcomes and biomarker analyses. American Association for Cancer Research (AACR Annual Meeting) 2017. 2017. Abstract 2986.

63. Nanda R, Chow LQ, Dees EC, Berger R, Gupta S, Geva R, Pusztai L, Pathiraja K, Aktan G, Cheng JD, Karantza V, Buisseret L. Pembrolizumab in patients with advanced triplenegative breast cancer: phase Ib KEYNOTE-012 study. JClin Oncol. 2016;34(21):2460-7. https://doi.org/10.1200/JCO. 2015.64.8931.

64. Senkus E, Cardoso F, Pagani O. Time for more optimism in metastatic breast cancer? Cancer Treat Rev. 2014;40(2):220-8. https://doi.org/10.1016/j.ctrv.2013.09. 015.

65. Dirix LY, Takacs I, Jerusalem G, Nikolinakos P, Arkenau HT, Forero-Torres A, Boccia R, Lippman ME, Somer R, Smakal M, Emens LA, Hrinczenko B, Edenfield W, Gurtler J, von HeydebreckA, Grote HJ, Chin K, Hamilton EP. Avelumab, an anti-PD-L1 antibody, in patients with locally advanced or metastatic breast cancer: a phase $1 \mathrm{~b}$ JAVELIN Solid Tumor study. Breast Cancer Res Treat. 2018;167(3):671-86. https:// doi.org/10.1007/s10549-017-4537-5.

66. Di Gioia D, Stieber P, Schmidt GP, Nagel D, Heinemann V, Baur-Melnyk A. Early detection of metastatic disease in asymptomatic breast cancer patients with whole-body imaging and defined tumour marker increase. Br J Cancer. 2015;112(5):809-18. https://doi.org/10.1038/bjc.2015.8.

67. Rohanizadegan M. Analysis of circulating tumor DNA in breast cancer as a diagnostic and prognostic biomarker.
Cancer Genet. 2018; https://doi.org/10.1016/j.cancergen. 2018.02.002.

68. Garcia-Murillas I, Schiavon G, Weigelt B, Ng C, Hrebien S, Cutts RJ, Cheang M, Osin P, Nerurkar A, Kozarewa I, Garrido JA, Dowsett M, Reis-Filho JS, Smith IE, Turner NC. Mutation tracking in circulating tumor DNA predicts relapse in early breast cancer. Sci Transl Med. 2015;7(302):302ra133. https://doi.org/10.1126/scitranslmed.aab0021.

69. Reuben JM, Krishnamurthy S, Woodward W, Cristofanilli $\mathrm{M}$. The role of circulating tumor cells in breast cancer diagnosis and prediction of therapy response. Expert Opin Med Diagn. 2008;2(4):339-48. https://doi.org/10.1517/ 17530059.2.4.339.

70. Soung YH, Ford S, Zhang V, Chung J. Exosomes in cancer diagnostics. Cancers (Basel). 2017; https://doi.org/10. 3390/cancers9010008.

71. Armand-Labit V, Pradines A. Circulating cell-free microRNAs as clinical cancer biomarkers. Biomol Concepts. 2017;8(2):61-81. https://doi.org/10.1515/bmc-2017-0002. 72. Best MG, Sol N, In't Veld S, Vancura A, Muller M, Niemeijer AN, Fejes AV, Tjon Kon Fat LA, Huis In't Veld AE, Leurs C, Le Large TY, Meijer LL, Kooi IE, Rustenburg F, Schellen P, Verschueren H, Post E, Wedekind LE, Bracht J, Esenkbrink M, Wils L, Favaro F, Schoonhoven JD, Tannous J, MeijersHeijboer H, Kazemier G, Giovannetti E, Reijneveld JC, Idema S, Killestein J, Heger M, de Jager SC, Urbanus RT, Hoefer IE, Pasterkamp G, Mannhalter C, Gomez-Arroyo J, Bogaard HJ, Noske DP, Vandertop WP, van den Broek D, Ylstra B, Nilsson RJA, Wesseling P, Karachaliou N, Rosell $\mathrm{R}$, Lee-Lewandrowski E, Lewandrowski KB, Tannous BA, de Langen AJ, Smit EF, van den Heuvel MM, Wurdinger T. Swarm intelligence-enhanced detection of non-smallcell lung cancer using tumor-educated platelets. Cancer Cell. 2017;32(2):238-252.e9. https://doi.org/10.1016/j. ccell.2017.07.004.

73. Uppal A, Wightman SC, Mallon S, Oshima G, Pitroda SP, Zhang Q, Huang X, Darga TE, Huang L, Andrade J, Liu H, Ferguson MK, Greene GL, Posner MC, Hellman S, Khodarev NN, Weichselbaum RR. 14q32-encoded microRNAs mediate an oligometastatic phenotype. Oncotarget. 2015;6(6):3540-52. https://doi.org/10.18632/ oncotarget.2920.

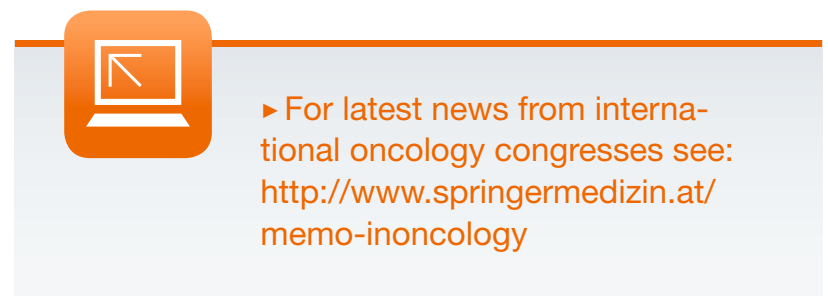

